J. Perinat. Med. 4 (1976) 78

\section{The effect of modern intensive monitoring in obstetrics on infant mortality and the incidence of hypoxia and acidosis}

\author{
E. Hochuli, J. Eberhard, O. Dubler
}

Frauenklinik des Kantonsspitals Münsterlingen
Modern techniques of monitoring have made it possible for obstetrics to aim at reducing perinatal mortality, hypoxia and acidosis. Infant mortality has been reduced to less than $1 \%$ with the diagnostic tools available today. This lower limit can only be further reduced by excluding factors that are difficult to change; e.g. nonviable deformities and "nonviable" premature deliveries. Hypoxia and acidosis ( $\mathrm{pH}$ less than 7.10 in the umbilical artery) are the cause of many neonatal deaths and may lead to later cerebral damage of children. It should be possible to reduce these to below $0.5 \%$.

Intensive monitoring is the monitoring of all pregnancies at risk using modern techniques. Eventually fetal monitoring should be part of all deliveries and should reach into the neonatal period. Whether this can be achieved was examined in our study of 10 years. An attempt was made to determine whether there was any correlation between the rates of mortality and acidosis and the techniques of monitoring as introduced through the years.

\section{Method}

The following methods were introduced successively during the last ten years:

Amnioscopy, blood microanalysis, urinary estrogen, internal cardiotokography with internal pressure determinations, umbilical blood analysis, amniotic fluid analysis, ultrasound (B-instrument) and HCSdeterminations. Every obstetric clinic caring for pregnancies at risk should have these techniques available.

\section{Curriculum vitae}

Ernst HOCHULI, M.D., lecturer at the Department of Obstetrics and Gynecoloby of Basel, is at present chairman of the Frauenklinik of the Kantonsspital Münsterlingen, Switzerland. Medical studies in Berne, Zurich, Geneva and Basel. He spent a great time of clinical work and research with Prof. Dr. O. Käser at the Frauenklinik St. Gallen, Switzerland and at the

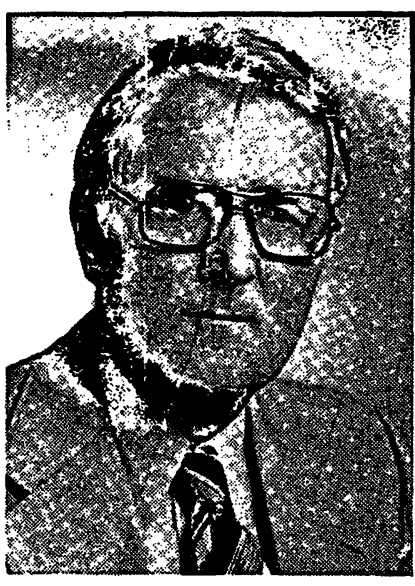

Department of Obstetrics and Gynecology at the University Frankfurt a.M., Germany. One of his main fields of interest is the whole complex of perinatology, especially concerning the efficiency of different methods to reduce perinatal mortality and morbidity.

Fig. 1 shows the number of examinations per patient per part of a year. This is a measure of the intensity of diagnosis. The abscissa shows time periods in years during which the technique became routine. It is apparent that cardiotokographic and umbilical blood examinations showed the largest increase. A further rise was seen in 197475 when more space became available making increased ambulatory care possible in collaboration with general practitioners.

Since Oct. 1 st 1974 cardiotokographs are present in all delivery rooms, making it possible to use "fetal monitoring" routinely. A central monitoring 


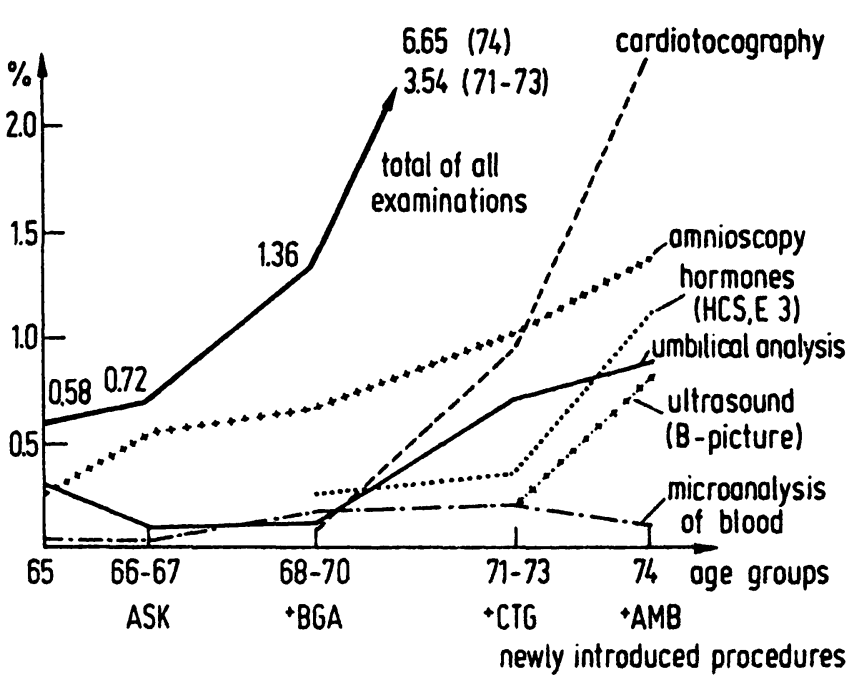

Fig. 1. Frequency of intensive monitoring in number of examinations per patient.

station with television facilitates this and permits storage of impulses.

This forms one unit together with a newborn reanimation department. The model of an "intensive circular unit" with its adnexes is depicted in Fig. 2 as it exists in our clinic.

\section{Results}

\subsection{Perinatal mortality}

Fig. 3 illustrates changes in perinatal mortality between 1965 and 1975. All infants over $1000 \mathrm{~g}$ that died within 7 days after birth are included in

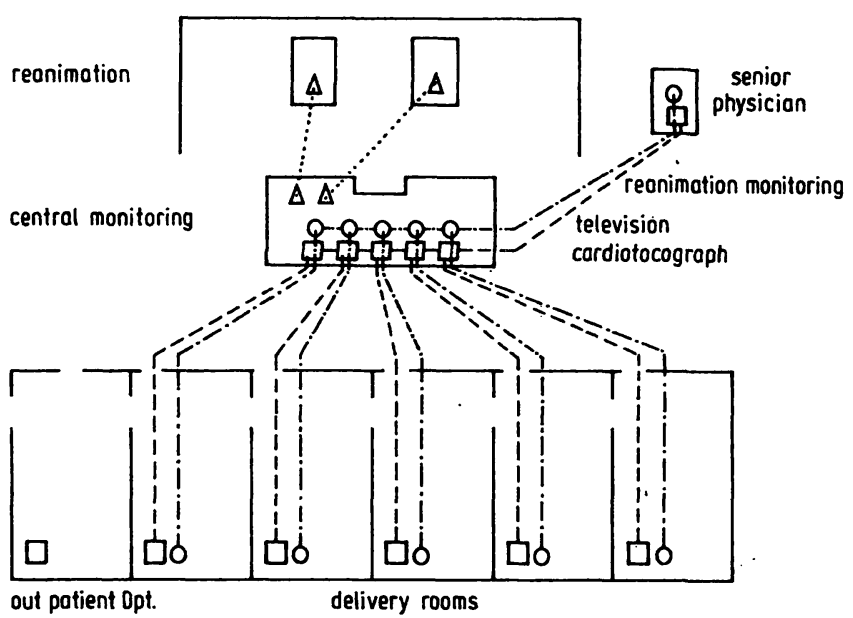

Fig. 2. Intensive monitoring unit

J. Perinat. Med. 4 (1976)

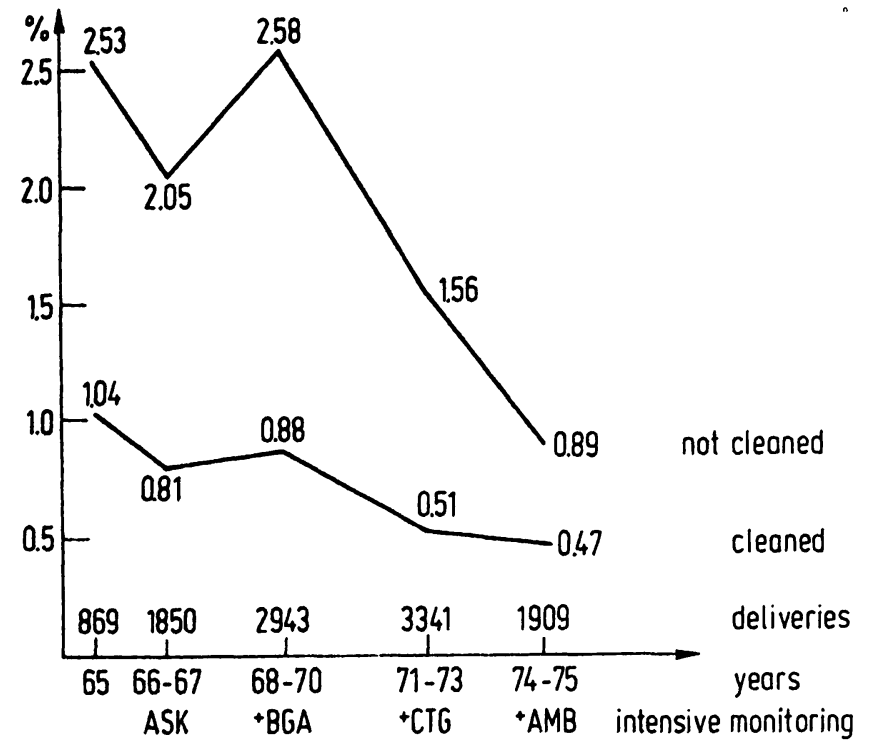

Fig. 3. Perinatal mortality between Jan. 1 st 1965 and Sept. 1 st 1975.

the "over-all" mortality (WHO definition). The net mortality excludes prematures weighing less than $2500 \mathrm{~g}$ at birth and nonviable defects. After cardiotokography, i.e. continuous recording of the fetal heart frequency when possible, the over-all mortality decreased $(\mathrm{p}<0.005)$.

At first a figure of $2 \%$ was attained. After the outpatient department was built this fell further to $0.89 \%$. Net mortality was $0.47 \%$. Since over-all mortality is greatly influenced by premature deliveries; the mortality of the latter group must be considered separately. It was found that over-all mortality did not decrease because the incidence of prematurity decreased. The latter was the same in all years, $6.2 \%$ in the last year. The mortality curve of prematures was the same as for all infants, i.e. in all years premature deaths formed $50 \%$ of all deaths.

Fig. 4 shows the effects of the various procedures on net mortality. Pre-labor mortality decreases as out-patient amnioscopy is introduced. Death during delivery is rare in all years $(1-2$ cases per 1000 deliveries) and could not be eliminated even with continuous monitoring. The decrease in total net mortality in the last years is due to a reduction in post partum deaths. 


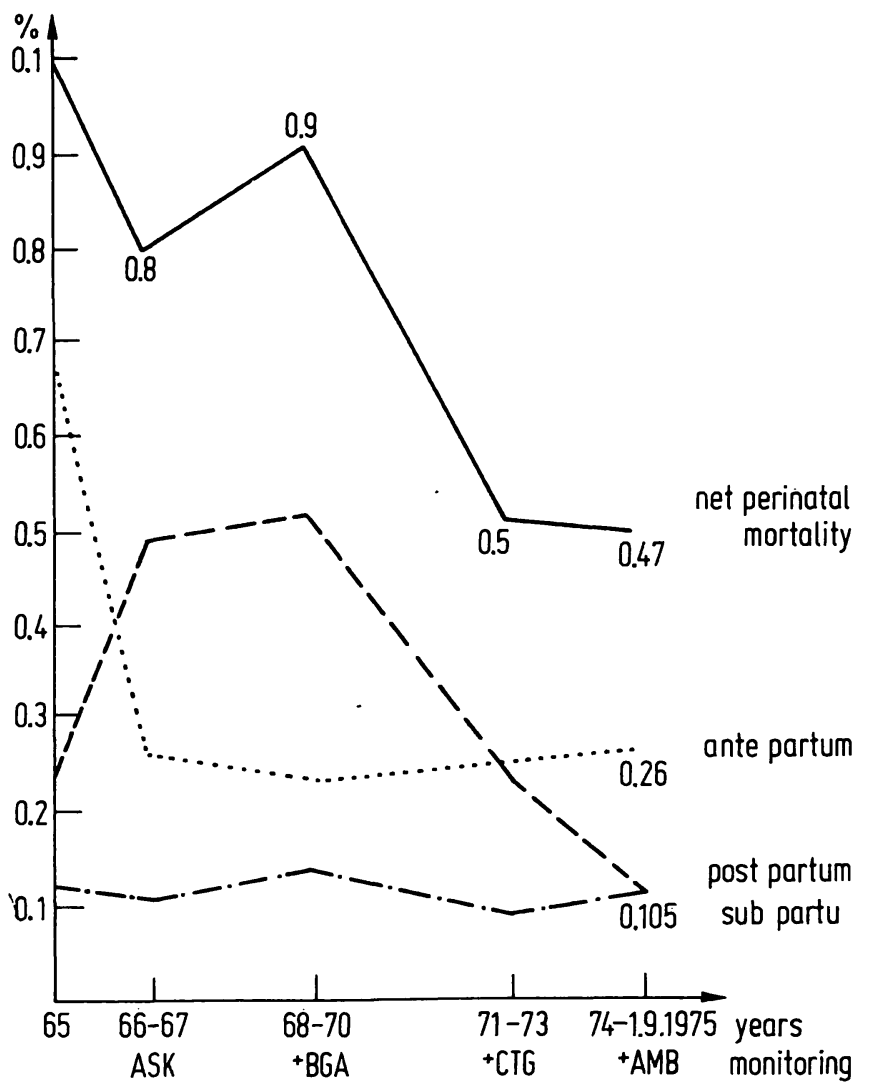

Fig. 4. Net perinatal mortality during different stages of labor.

\subsection{Hypoxia and acidosis}

The acid-base state of umbilical blood must be determined in order to determine different sates of acidosis [7, 9]. Hence, since 1972 the acidity of umbilical blood is routinely determined using the criteria of SALING and WULF [17]. Tab. I shows medium (pH 7.09-7.00) and severe (less than 7.00) acidosis in two groups.

Tab. I. Incidence of progressed and severe acidosis

\begin{tabular}{lccc}
\hline \multicolumn{2}{c}{ years } & $1970-1974$ & 1975 up to Sept. 1 st) \\
\hline $\mathrm{N}$ & 3291 & 674 \\
& & & \\
pH & $7,09-7,00$ & $1.70 \%$ & $0.45 \%$ \\
pH & $<7.00$ & $0.33 \%$ & $0 \%$ \\
pH & $<7.10$ & $2.03 \%$ & $0.45 \%$ \\
\hline
\end{tabular}

Between 1970 and 74 the first group contained $2.03 \%$ acidoses (electronic monitoring only if several risk factors present) and this was decreased to $0.45 \%$ (up to Sept. $1 \mathrm{st}, 1975$ ) after introduction of general fetal monitoring, although the number of cases was relatively small.

\section{Discussion}

There is no doubt that intranatal monitoring is effective. The reduction in perinatal mortality and acidotic morbidity amply demonstrates this $[1,2$, $4,5,6,8,10,13,14,15,16,18,19,20]$. Already in 1969 PAKZAD and SALING attained a perinatal mortality of $2.13 \%$ by microblood analyses of fetuses at risk. Without this monitoring mortality was $10.1 \%$. Others $[12,19]$ have had similar results. In 1972 the number of monitored cases in Basel was already $30-40 \%$. HeINRICH et al. [5] consider the cardiotokogram to be the prerequisite for good monitoring. Intranatal death can be avoided by its use. Their gross perinatal mortality was $1.42 \%$ in 1974; the net mortality $0.73 \%$. $30 \%$ of all cases were monitored. PAUL and HoN [14] found a $1 \%$ mortality rate in a group of monitored deliveries $(n=6750)$ whereas this was higher at $1.7 \%$ in a nonmonitored completely normal group ( $\mathrm{n}=$ 21422). There were $0.13 \%$ deaths during labor in the monitored and $0.44 \%$ in the non-monitored group.

The decrease in gross perinatal mortality in our clinic (from 2.58 in $1968-70$ to $0.89 \%$ in $1974-$ 75 ) is probably due to several factors. In addition to improved perinatal monitoring, improved neonatal reanimation and intensive care undoubtedly played a role. The significant decrease ( $p<0.005$ ) of gross mortality to $1.56 \%$ in $1971-$ 73 indicates that continuous recording of the fetal heart rate is of great value. This made it possible to reduce the incidence of hypoxic and acidotic states. Prematures also gained from this procedure; since acidosis as a companion of RDS has a great effect on premature mortality. This was also observed by PAUL and HoN [14]. The introduction of perinatal monitoring and improved and mo extensive out-patient care further reduced perinatal mortality as was also observed by others [4].

Total mortality is reduced mainly because postnatal mortality falls (Fig. 4). As a result of intensive monitoring fewer and fewer infants have to be 
transferred to the intensive care unit. Prenatal mortality has also been reduced. However, mortality during labor remained unchanged. (0.1 to $0.2 \%)$. These cases consist of patients admitted too late for intensive monitoring and of those in which perhaps a human error played a role. A test for the efficacy of continuous monitoring, however, is not mortality but postnatal hypoxia and acidosis and these are effectively decreased.

Intrauterine hypoxia and acidosis contribute to a large extent towards perinatal deaths. Their sociomedical significance is enormous. About $60 \%$ of cerebrally impaired children underwent a phase of hypoxia and acidosis during gestation. In many cases the obstetrician is at foult. A figure of $0.2 \%$ of all live born children that remain alive with some impairment and twice that number who grow up with organically conditioned psychosomatic disturbances as $\mathrm{P}$ risk cases is probably not exaggerated [3].

The incidence of pathological EEGs is also affected by monitoring [11]. Monitoring decreases this incidence from 17.6 to $5 \%$. BoENISCH and SALING [2] showed that the number of acidotic and clinically depressed infants decreased significantly in the years $1970-73$. In 1973 only $1.3 \%$ of all newborns had advanced or severe acidosis $(\mathrm{pH}<7.10)$, $1.5 \%$ severe or medium clinical depression and $0.3 \%$ both.

Only a general analysis of umbilical blood gases (as practised by us since 1971) and the gradation of the values obtained according to the degree of acidosis make it possible to assess all patients and is essential for future treatment. The number of severe and progressing acidoses $(\mathrm{pH}<7.10)$ should have the same weight as perinatal mortality when assessing the efficacy of a clinic.

In the presence of one or more risk factors when intensive monitoring was used, we were surprised to find no alarming symptoms in about $50 \%$ of the newborns that were monitored discontinuously. Evidently monitoring according to the accepted risk factors cannot assess the actual risk sufficiently well. Hence it may be concluded that only general intensive monitoring during labor can lead to better results. At the same time an attempt is made to record the fetal heart rate continuously and to assess quantitatively uterine contractions by intrauterine pressure recordings. This has been neglected by most. BEARD [1] is of the opinion that a selection of patients for fetal monitoring is only a partial solution to deaths during labor and that only continuous monitoring of all patients can prevent the death due to asphyxia that occurs during labor. Before general intensive monitoring was introduced we found an incidence of $2.03 \%$ progressed and severe acidosis in 3291 biochemically analysed newborns [9]. This high frequency is influenced by the fact that analyses were performed only if indicated (suspicion of acidosis, e.g. by fetal depression). After intesive monitoring was introduced this figure was reduced to $0.45 \%$ in the first 8 months of 1975. Even though a smaller group of cases was analysed $(n=674)$ the trend is obvious. It must also be stressed that not a single case with pH less than 7.00 occurred. Hence only general monitoring can prevent and decrease the incidence of hypoxia and acidosis.

\section{Summary}

We consider intensive monitoring to be fetal monitoring during labor and in the newborn period of all births using the most efficient methods. During the last ten years we have sequentially used the following techniques: Amnioscopy, blood analysis, estrogen determinations in urine, external and internal cardiotokography and internal pressure determinations, gas analyses of umbilical blood, amniotic fluid analyses (phospholipids), ultrasound (Bapparatus) and HCS determinations. All clinics dealing with risk pregnancies should have these techniques available.

Total perinatal mortality decreased to below $2 \%$ after introduction of cardiotokography. During the last year it decreased to $0.89 \%$. Premature mortality shows the same decrease and is $50 \%$ of total mortality. The frequency of premature deliveries remained unchanged at $6.2 \%$. Both improved intensive monitoring and neonatal reanimation and intensive care contributed to the reduction of perinatal mortality. Continuous heart rate recordings make it possible to uncover hypoxic and acidotic states in time and this is of particular value for the premature infant. The incidence of acidosis ( $\mathrm{pH}<7.10$ ) was $2.03 \%$ before monitoring was introduced and fell to $0.45 \%$ this year when intensive monitoring became the rule. No $\mathrm{pH}$ lower than 7.0 was found this year. It is thus not sufficient to monitor only cases at risk, since in about $50 \%$ of infants 
born with acidosis no alarming symptoms were found that would have indicated the need for intensive monitoring.

Conclusion: Infant mortality shoud be reduced to less than $1 \%$ if the diagnostic tools available are applied. Below this nonviable infants limit further improvement. Perinatal hypoxia and acidosis (below pH 7.10) should also be lower than $0.5 \%$ but'at least lower than $1 \%$.

Keywords: Intensive monitoring in pregnancy and during labor, general fetal monitoring during labor, perinatal hypoxia and acidosis, perinatal mortality.

\section{Zusammenfassung}

Der Einfluß der modernen Intensivüberwachung in der Geburtshilfe auf die kindliche Mortalität und Hypoxie und Azidosemorbidität

Unter Intensivüberwachung verstehen wir eine solche aller Risikoschwangerschaften, die fließend in ein generelles subpartuales "fetal monitoring" des gesamten Geburtenkollektives überleitet und schließlich in der Neugeborenenperiode endet. Die Überwachung hat dabei mit Methoden größtmöglichster Effizienz zu erfolgen.

In den letzten 10 Jahren kamen an unserer Klinik sukzessive folgende Methoden der Überwachung zur Anwendung: Amnioskopie, Mikroblutgasanalysen, Östrogenbestimmungen im Urin, externe und interne Kardiotokographie zusammen mit interner Druckmessung, Nabelschnurblutgasanalysen, Fruchtwasseranalysen (Phospholipide), Ultraschalluntersuchungen (B-Gerät) und HCS-Bestimmungen. Jede geburtshilfliche Klinik, die Risikoschwangerschaften und -geburten betreut, sollte über dieses diagnostische Instrumentarium verfügen können.

Nach Einführung der Kardiotokographie sinkt die ungereinigte perinatale Mortalität erstmals unter eine Ziffer von $2 \%$ ab. In der letzten Jahresgruppe (1974-1975) ist noch einmal eine Reduktion um beinahe das Doppelte, nämlich auf $0,89 \%$ zu verzeichnen. Die Frühgeburtensterblichkeit verhält sich analog und macht $50 \%$ der ungereinigten Gesamtmortalität aus. Die Frühgeburtenfrequenz hingegen war während der letzten Jahre praktisch dieselbe, zuletzt 6,2\%. Das kontinuierliche Absinken der ungereinigten perinatalen Mortalität bis auf $0,89 \%$ wird auf das Zusammenwirken verschiedener Faktoren zurückgeführt. Außerhalb der verbesserten Intensivüberwachung während der Schwangerschaft und unter der Geburt, zuletzt der generellen Überwachung aller Patienten sub partu, spielen auch die optimierte Neugeborenenreanimation und neonatale Intensive-Care eine wichtige Rolle. Immerhin läßt der erhebliche Rückgang der Sterblichkeit nach Einführung der Kardiotokographie darauf schließen, daß es mit der kontinuierlichen Registrierung der fetalen Herz- frequenz gelingt, hypoxische und ażidotische Zustände mit eventuell letalen Folgen für das Neugeborene frühzeitig zu erfassen, wovon ganz besonders auch die Frühgeburten profitieren.

Vor der Einführung der generellen elektronischen Überwachung sub partu konnten wir in einem Kollektiv von 3291 biochemisch analysierten Neugeborenen eine Inzidenz von 2,03\% fortgeschrittenen und schweren Azidosen feststellen. Nachdem wir mit der generellen Intensivïberwachung begonnen hatten, zeigen die ersten Zahlen (1. 1. 75-1. 9. 75) bereits ein starkes Absinken der Azidosefrequenz auf $0,45 \%$. Dabei ist besonders hervorzuheben, daß in dieser Zeit kein Fall mit einer schweren Azidose mit einem $\mathrm{pH}$ von weniger als 7,00 zu verzeichnen war. Eine Intensivüberwachung nach Indikationen (je nach Vorhandensein eines oder mehrerer Risikofaktoren) genügt demzufolge trotz großzügiger Auslegung des Risikokataloges nicht, die Azidosefrequenz entscheidend zu senken, denn bei ca. 50\% der mit Azidose geborenen Neugeborenen waren mit den herkömmlichen Mitteln (diskontinuierliche Überwachung unter der Geburt) keine Alarmsymptome vorhanden, die eine Indikation zur Intensivüberwachung ergeben hätten.

Schlußfolgerungen: Die kindliche Sterblichkeit sollte unter großzügiger Anwendung der heute zur Verfügung stehenden diagnostischen Verfahren (inkl. generelle Intensivüberwachung sub partu) auf weniger als $1 \%$ reduziert werden können. Diese untere Grenze wird nur noch durch wenig beeinflußbare Faktoren wie durch die lebensunfähigen Mißbildungen und durch die ,lebensunfähigen“" Frühgeburten limitiert. Die perinatale Hypoxie und Azidosemorbidität (pH-akt. im Nabelschnurarterienblut $<7,10$ ), die nicht nur mit einem hohen Anteil an den ad exitum kommenden Neugeborenen beteiligt ist, sondern auch eine außerordentliche prospektive Bedeutung hat (cerebral geschädigte Kinder) sollte ebenfalls wenn möglich unter $0,5 \%$, sicher aber unter $1 \%$ gesenkt werden können.

Schlüsselwörter: Generelles fetales Monitoring sub partu, Intensivüberwachung in graviditate und sub partu, perinatale Hypoxie und Azidosemorbidität, perinatale Mortalität.

\section{Résumé}

Influence de la surveillance intensive moderne en obstetrique sur la mortalité infantile, l'hypoxie et la morbidité acidosique

Nous entendons par surveillance intensive celle de toutes les grossesses risquées qui conduit à un «fetal monitoring》 subpartuel général de tout le groupe des accouchements

et se termine à la période des nouveaux-nés. Cette surveil-
lance doit se faire à l'aide de méthodes d'une efficacité
maximale.
Au cours des 10 dernières années, nous avons appliqué
dans notre hôpital les méthodes successives de surveillance
d'amnioscopie, d'analyses des gaz microsanguins, de 
définitions d'oestrogène dans l'urine, de cardiotocographie externe et intcrne conjuguée avec la tonométrie interne, d'analyses des gaz du sang ombilical, d'analyses du liquide amniotique (phospholipide), d'examens ultrasoniques (Appareil B) et de définitions HCS. Tout service de maternité s'occupant de grossesses et accouchements difficiles devrait pouvoir disposer de toutes ces méthodes de diagnostic.

Après avoir introduit la cardiotocographie dans notre établissement, nous avons pu constater une première baisse de la mortalité périnatale non rectifiée à moins de $2 \%$ et, pour le dernier groupe d'année (1974-75), une nouvelle réduction de près du double, c.à.d.jusqu'à $0,89 \%$. Nous observons une courbe similaire pour la mortalité des prématurés qui représente $50 \%$ de toute la mortalité non rectifiée. La fréquénce des accouchements prématurés, par contre, est restée pratiquement identique au cours des dernières années et était en dernier lieu de $6,2 \%$. La baisse continue de la mortalité périnatale non rectifiée jusqu'à $0,89 \%$ est dûc à l'effet conjugué de divers facteurs. Outre l'amélioration de la surveillance intensive pendant la grossesse et l'accouchement, en dernier lieu de la surveillance générale de toutes les parturientes sub partu, l'extension de la réanimation des nouveaux-nés et des soins intensifs néonataux jouent aussi un rôle important. Quoiqu'il en soit, la baisse considérable de la mortalité conséquente à l'introduction de la cardiotocographie permet de conclure qu'en enregistrant de façon continue la fréquence cardiaque du foetus, il est possible de dépister à temps des états hypoxiques et acidosiques avec d'éventuelles suites létales pour le nouveau-né, surtout en ce qui concerne les accouchements prématurés.

Avant d'avoir introduit la surveillance électronique générale sub partu, nous avions enregistré dans un groupe de 3291 nouveauxnés ayant subi des analyses biochimiques une incidence de $2,03 \%$ d'acidoses graves et avancées. Après avoir commencé la surveillance intensive générale, nous avons observé dès les premiers résultats (1.1.751. 9. 75) une forte baisse de la fréquence d'acidose jusqu'à $0,45 \%$. Il convient de souligner à ce propos que nous n'avons eu durant cette période aucun cas d'acidose grave avec un $\mathrm{pH}$ inférieur à 7,00. Mais bien qu'on eut établi une liste très précise des divers risques, on a constaté qu'une surveillance intensive sur indications déterminées par la présence d'un ou de plusieurs facteurs de risque, ne suffit pas à faire baisser de façon significative la fréquence d'acidose du fait que, pour environ $50 \%$ des nouveauxnés acidosiques, les procédés usuels de surveillance discontinue en cours d'accouchement ne permettent pas de dépister les symptômes irıquiétants qui nécessiteraient un contrôle intensif.

Conclusions: L'application étendue des méthodes de diagnostic disponibles aujourd'hui (y compris la surveillance intensive générale sub partu) devrait permettre de réduire à moins de $1 \%$ la mortalité infantile. La réduction de ce degré à un niveau encore inféricur n'est plus limitée que par des facteurs difficilement influençables tels que les malformations nonviables et les accouchements prématurés «nonviables». L'hypoxic périnatale et la morbidité acidosique (pH act du sang artériel ombilical $<7,10$ ), qui non seulement sont en grande partie à l'origine des morts-nés, mais ont aussi une importance extrêmement prospective (enfants avec lésions cérébrales), devraient, de même, pouvoir être réduites à moins de $0,5 \%$ si possible, ou, en tout cas, à moins de $1 \%$.

Mots-clés: Hypoxie périnatale et morbidité acidosique, monitoring foetal général sub partu, mortalité périnatale, surveillance intensive en cours de gravidité et sub partu.

\section{Bibliography}

[1] BEARD, R. W.: The detection of fetal asphyxia in labor. Pediatrics 53 (1974) 157

[2] BOENISCH, H., E. SALING: A combined clinicalbiochemical scoring of the newborn. Results of the past four years. J. Perinat. Med. 2 (1974) 122

[3] EWERBECK, H.: Zerebrale Spätschäden nach Risikogeburten. Geburtsh. u. Frauenheilk. 31 (1971) 901

[4] GABERT, H. A., M. A. STENCHEVER: Continous electronic monitoring of fetal heart rate during labor. Amer. J. Obstet. Gynec. 115 (1973) 919

[5] HEINRICH, J., G. SEIDENSCHNUR: Methoden und Ergebnisse der intranatalen Intensivüberwachung II. Zbl. Gynäk. 96 (1974) 513

[6] HEINRICH, J., G. SEIDENSChNUR, H. HOPP, E. KOEPCKE, M. RISSMANN: Kardiotokographie, geburtsmedizinische Entscheidung und perinatologische Ergebnisse. Zbl. Gynäk. 97 (1975) 257

[7] HOCHULI, E.: Die kindliche Hypoxie und Azidosemorbidität. Die Bedeutung der Nabelschnurblutgasanalyse. Schweiz. med. Wschr. 104 (1974) 1717

[8] HOCHULI, E.: Biochemische Beurteilung des Neugeborenen. Zbl. Gynäk. 97 (1975) 171
[9] HOCHUl, E., F. NAGL, O. DUBlER: Hypoxieund Azidosemorbidität - Eine kritische Studie anhand von 3291 Nabelschnurblutgasanalysen und ihre Konsequenzen. Z. Geburtsh. u. Perinat. 179 (1975) 112

[10] KELLY, V. C., D. KULKARNI: Experiences with fetal monitoring in a Community Hospital. Obstet. and Gynec. 41 (1973) 818

[11] KRAUSE, W., K. H. DAUTE, E. KLUST, H. FRITZSCHE: EEG-Befunde bei elektronisch überwachten Risikogeburten. Zbl. Gynäk. 97 (1975) 966

[12] KUBLI, F.: Zur Problematik der fetalen Intensivüberwachung. Melsunger med. Mitt. 45 (1971) 129

[13] LOW, J. A., S. R. PNACHAM, D. WORTHINGTON, R. W. BOSTON: The incidence of fetal asphyxia in six hundred high-risk monitored pregnancies. Amer. J. Obstet. Gynec. 121 (1975) 456

[14] PAUL, R. H., E. H. HON: Clinical fetal monitoring. Amer. J. Obstet. Gynec. 118 (1974) 529

[15] PAKZAD, M., E. SA LING: Perinatale Mortalität von Kindern mit Distresshinweisen vor dem Einsatz neuzeitlicher geburtshilflicher Überwachungsverfahren. Dtsch. med. Wschr. 94 (1969) 1563 
[16] QUilligan, E. J., R. H. PAUL: Fetal monitoring: Is it worth it? Obstet. and Gynec. 45 (1975) 96

[17] SALING, E., H. WULF: Zustandsdiagnostik beim Neugeborenen - Gruppeneinteilung. Fortschr. Med. 89 (1971) 12

[18] SHENKER, L.: Clinical experiences with fetal heart rate monitoring of one thousand patients in labor. Amer. J. Obstet. Gynec. 115 (1973) 1111
[19] SEIDENSCHNUR, G., J. HEINRICH: Methoden und Ergebnisse der intranatalen Intensivüberwachung (I). Zbl. Gynäk. 95 (1973) 1101

[20] TUTERA, G., R. L. NEWMAN: Fètal monitoring: Its effect on the perinatal mortality and cesarean section rates and its complications. Amer. J. Obstet. Gynec. 122 (1975) 750

Received October 13, 1975. Accepted December 15, 1975.

PD Dr. med. E. Hochuli Kantonsspital Münsterlingen CH-8596 Münsterlingen 